\title{
Inner-ear abnormalities and their functional consequences in Belgian Waterslager canaries (Serinus canarius)
}

\author{
Otto Gleich ${ }^{\mathrm{a}, *}$, Robert J. Dooling ${ }^{\mathrm{b}}$, Geoffrey A. Manley " \\ "Institut für Zoologie der Technischen Universität München, Lichtenbergstraßse 4. 85747 Garching. FRC; \\ ${ }^{\circ}$ Department of Psychology, Unic ersity of Maryland, College Park, MD 20742, USA
}

Received 29 November 1993; revision received 17 May 1994; accepted 22 May 1994

\begin{abstract}
Recent reports of elevated auditory thresholds in canaries of the Belgian Waterslager strain have shown that this strain has an inherited auditory deficit in which absolute auditory thresholds at high frequencies (i.e. above $2.0 \mathrm{kHz}$ ) are as much as $40 \mathrm{~dB}$ less sensitive than the thresholds of mixed-breed canaries and those of other strains. The measurement of CAP audiograms showed that the hearing deficit is already present at the level of the auditory nerve (Gleich and Dooling, 1992). Here we show gross abnormalities in the anatomy of the basilar papilla of Belgian Waterslager canaries at the level of the hair cell. The extent of these abnormalities was correlated with the amount of hearing deficit as measured behaviorally.
\end{abstract}

Key words: Bird; Canary; Cochlea; Hair-Cell; Pathology; Deafness

\section{Introduction}

Canaries have been a favorite species of aviculturists for some time, and were bred for their plumage and distinctive songs (Guttinger, 1985; Stresemann, 1923). One strain, the Belgian Waterslager canary, hereafter referred to as 'Waterslager', is particularly noted for its loud, clear song. Canaries of this strain have been the focus of scientific studies on the behavior and neurobiology of vocal learning (Marler and Waser, 1977; Waser and Marler, 1977) as well as neurogenesis in the vertebrate central nervous system (Nottebohm, 1981; Brown and Bottjer, 1993).

Recent investigations of hearing in Waterslagers have shown that birds of this strain have thresholds at high frequencies (i.e. above $2 \mathrm{kHz}$ ) that are $20-40 \mathrm{~dB}$ higher than the thresholds from those of other strains of canaries and of other birds (Dooling, 1982; 1992; Okanoya and Dooling, 1985; 1987). The behavioral

\footnotetext{
* Corresponding author. (Present address) HNO-Klinikum, Universität Regensburg, Postfach. 93042 Regensburg. FRG. Fax: + 49 (941) 9449402 .
}

evidence suggests that this auditory deficit is inherited, in that thresholds from canaries obtained from crossbreeding a Waterslager and a German Roller canary vary from the completely normal pattern of threshold sensitivity found in German Rollers to the elevated pattern of threshold sensitivity found in Waterslagers, with some offspring showing an intermediate pattern (Okanoya et al., 1990).

Recently completed compound action potential (CAP) measurements from the auditory nerve in response to tone pulses in both normal and Waterslager canaries showed that thresholds calculated from CAP recordings showed much worse sensitivity for Waterslagers than for canaries of other strains. (Gleich and Dooling, 1992). These results suggested that the proximate cause of elevated thresholds in Waterslagers lies in the peripheral auditory system; most probably within the cochlea.

In order to identify potential anatomical substrates for this problem, we decided to study the basilar papillae of birds whose auditory performance had been tested either behaviorally or by measuring compound action potentials, to attempt a correlation between observations of basilar-papilla morphology and the au- 
ditory performance. The care and use of the animals reported on in this study was according to German and US laws.

\section{Methods}

\section{Behavioral audiograms}

One female and one male Waterslager canary and one canary of mixed breed were obtained from local dealers in the USA. All three birds were estimated to be between 12 and 18 months old.

The apparatus for the behavioral audiometry has been described previously (Okanoya and Dooling, 1985; 1987 ; 1990a,b). Briefly, a two-key operant panel was constructed using sensitive microswitches and lightemitting diodes (LEDs). The panel was mounted on an automatic feeder just above the feeder opening. The operant apparatus was attached to one wall of a wire cage $(25 \times 25 \times 25 \mathrm{~cm})$. A loudspeaker was mounted 50 $\mathrm{cm}$ above the operant apparatus so that it was $58 \mathrm{~cm}$ from the bird's head when it was sitting on the perch and facing the response panel. The entire apparatus was suspended in a small animal Industrial Acoustics Booth $(0.8 \times 0.6 \times 0.6 \mathrm{~m})$. Sound stimuli were generated digitally, filtered at $\pm 10 \%$ of the test-tone frequency and passed through a programmable attenuator (Tucker-Davis), and amplified. Sound-field calibration was accomplished by placing the $1 / 2$ inch microphone of a General Radio 1982 Sound Level Meter in the position normally occupied by the bird's head during testing. All experimental events including sound delivery, schedule of reinforcement and data collection were controlled by a micro-computer as described elsewhere (Okanoya and Dooling, 1990a,b).

The audiometric procedure was similar to that used in previous studies of auditory sensitivity in budgerigars and zebra finches (Okanoya and Dooling, 1990a,b). The birds were trained, by operant conditioning with food reinforcement, to peck one key (observation key) repeatedly when they did not hear a tone and to peck the other key (report key) when they did. Initial training used a $2.0 \mathrm{kHz}$ pure tone, $200 \mathrm{~ms}$ in duration with a rise/fall time of $5 \mathrm{~ms}$ presented at a level of $70 \mathrm{~dB}$ SPL and at the rate of $1 / 450 \mathrm{~ms}$. The training phase continued until the birds attained a level of about $80 \%$ correct responses combined with a false alarm rate of less than $20 \%$ for a session of 70 trials.

During testing, the sound pressure level of the test tone varied over a range of $20-40 \mathrm{~dB}$, depending on the frequency of the test tone. If the bird pecked the report key within $2 \mathrm{~s}$ after the presentation of a tone, it was reinforced on $70 \%$ of the trials with a $2 \mathrm{~s}$ access to food. Catch trials were presented on $30 \%$ of the trials in a 70-trial session. A response on the report key during a sham trial (a false alarm) was punished with a
$10-20 \mathrm{~s}$ timeout period during which all lights in the test chamber were extinguished.

Since complete audiograms have already been published comparing Waterslager and non-Waterslager canaries, we only tested these birds at four frequencies: $1.0,2.0,2.86$, and $4.0 \mathrm{kHz}$. Birds were tested in sessions of 70 trials, several times a day. The method of constant stimuli was used for the presentation of test tones of different sound-pressure levels. Threshold was defined as the SPL resulting in a correct response rate of $50 \%$ (corrected for the false alarm rate; Okanoya and Dooling, 1990a,b). Each bird was tested a minimum of 35 trials at each frequency and sound-pressure levelcombination.

\section{Compound action potential audiograms}

A male and a female Waterslager canary were obtained from a breeder in Germany. One female canary of mixed breed was obtained from a local dealer in Germany. At the time of the experiments, the birds were approximately one year old.

The compound action potential measurements of the birds whose cochleae were analyzed for this study were part of another series of experiments that are described and published in detail elsewhere (Gleich and Dooling, 1992; Gleich et al., unpublished data). Briefly, the compound action potential (CAP) was recorded with a scala-tympani electrode in anesthetized animals. Stimuli (tone pips, $10 \mathrm{~ms}$ duration, 1 $\mathrm{ms}$ rise/fall time, $3-4 / \mathrm{sec}$ ) were presented through a closed, calibrated sound system. Responses to 64 stimulus repetitions were averaged. Test frequencies ranged from 0.5 to $6 \mathrm{kHz}$. The test sound pressure was increased in $5 \mathrm{~dB}$ steps from well below to well above threshold, or to the maximum output of the sound system (approximately $100 \mathrm{~dB}$ SPL). Threshold for a given frequency was defined as the sound pressure where the CAP amplitude reached $6 \mu \mathrm{V}$ and further increased at the next higher test sound pressure.

\section{Morphology of the basilar papilla}

The cochleae of the experimental birds where behavioral or CAP audiograms had been measured (see above) were prepared for scanning electron microscopy (SEM) as described previously (Gleich and Manley, 1988). After fixation (2.5\% glutaraldehyde, $15 \%$ aqueous picric acid in $0.1 \mathrm{M}, \mathrm{pH} 7.4$ phosphate buffer) the bony wall of the cochlea, the tegmentum vasculosum and the tectorial membrane were removed carefully from the specimens to expose the basilar papilla surface. After dehydration, critical-point drying and gold coating, the cochleae were mounted on stubs and examined by scanning electron microscopy.

Photographs of the papillar surface were taken at low magnifications to construct an overview of each papilla (e.g. Fig. 2). For detailed analysis, high-power SEM pictures were taken systematically to reconstruct 
a strip of $120-150 \mu \mathrm{m}$ width across the papilla (final magnifications 2000-4000times) at distances of 20, 50 and $80 \%$ of the papillar length from the basal end of the papilla (eg. Fig. 5). On these reconstructions, cells were selected for which the number of stereovilli and the apical hair-cell area could be determined. In each of the selected cells, the number of stereovilli, the distance of the cell to the neural edge of the papilla and the apical hair-cell area were measured. The area measurements were performed using the program HVEM 3D (Laboratory for High Voltage Electron Microscopy, University of Colorado).

Due to the abnormalities found in the Waterslager canaries (see results), it was impossible to determine many of the parameters used to characterize morphological gradients in other birds (e.g. orientation of bundles etc; Gleich and Manley, 1988; Fischer et al., 1988). In order to obtain a more quantitative idea of the degree of pathology in the Waterslager basilar papilla we asked 5 volunteers who were not experienced with SEM evaluation of the avian basilar papilla to classify the hair cells in high-power reconstructions of papilla segments 20,50 and $80 \%$ from the base. The volunteers were asked to inspect the reconstructions from the controls in order to have a reference for the later classification of hair cells in the Waterslager papillae. They were informed that each hair cell is surrounded by a microvilli border and has an orderly bundle of stereovilli. They were then asked to assign a grade between 1 and 5 to each hair cell on the reconstructions from the Waterslager papillae. Grade 1 stands for a hair cell that is classified as normal compared with the control cochleae. Grades 2 to 5 indicate slight to very severe abnormality of the hair cell. The grades were written on a transparency laid over the photographic reconstruction, so that the marks for different cells and from different volunteers could be unequivocally assigned.

\section{Results}

\section{Audiograms of experimental birds}

Behavioral audiograms of two Waterslagers (WS1, WS2) and one mixed-breed canary (NC1) are shown in Fig. 1a. The mixed-breed canary (NC1, heavy continuous line) showed thresholds that were slightly better than those for other normal canaries (thin continuous line) studied previously. The two Waterslager canaries (heavy dashed lines) showed elevated thresholds near those previously measured in other Waterslagers (thin dotted line). One bird (WS1, open triangles) had thresholds very close to the average of those described for other Waterslager canaries, the other Waterslager (WS2, open circles) had thresholds that were slightly worse than this.
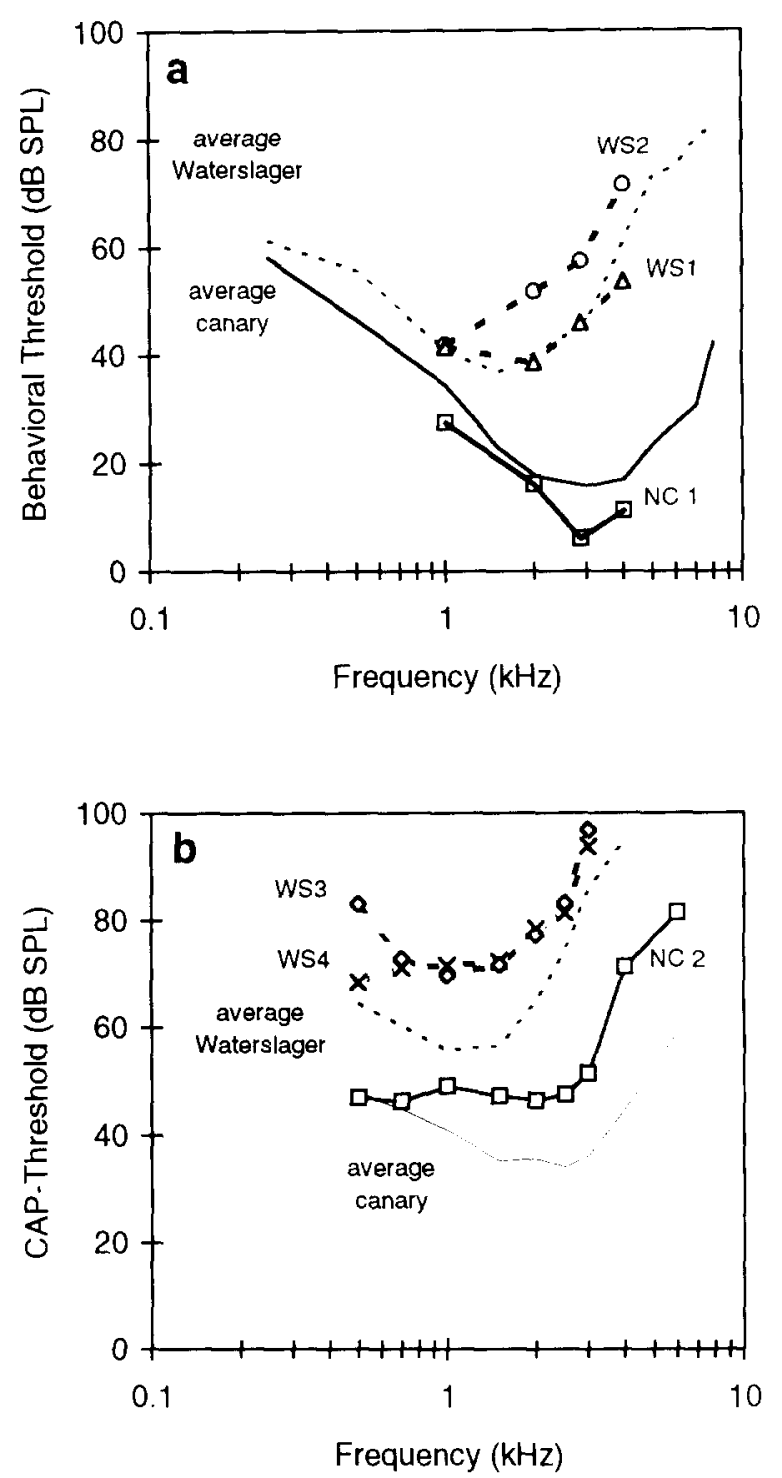

Fig. 1. (a,b) Audiograms of the birds whose cochleate were used for the morphological analysis. The heavy continuous lines with open squares code data from non-Waterslager canaries. The heavy dotted lines show results from Waterslager canaries. A label at each audiogram indicates the bird number for comparison with other figures and Table 1. The thin continuous and dotted lines show average audiograms from non-Waterslager and Waterslager canaries, respectively. (a) Behavioral audigrams, (b) compound action potential audiograms.

The CAP audiograms of two other Waterslager canaries confirmed that they had elevated thresholds across the frequency range as compared to mixed breed canaries. Fig. 1b shows the CAP audiograms of the cochleae from the control canary ( $\mathrm{NC} 2$, heavy continuous line, open squares) and those of the Waterslagers (WS3, WS4, heavy dotted lines, diamonds and crosses) that were used for this anatomical study. As in other studies that measured CAP thresholds in birds we found considerable interindividual variability (Gummer et al., 1987; Patuzzi and Bull, 1991). Thresholds of NC2 


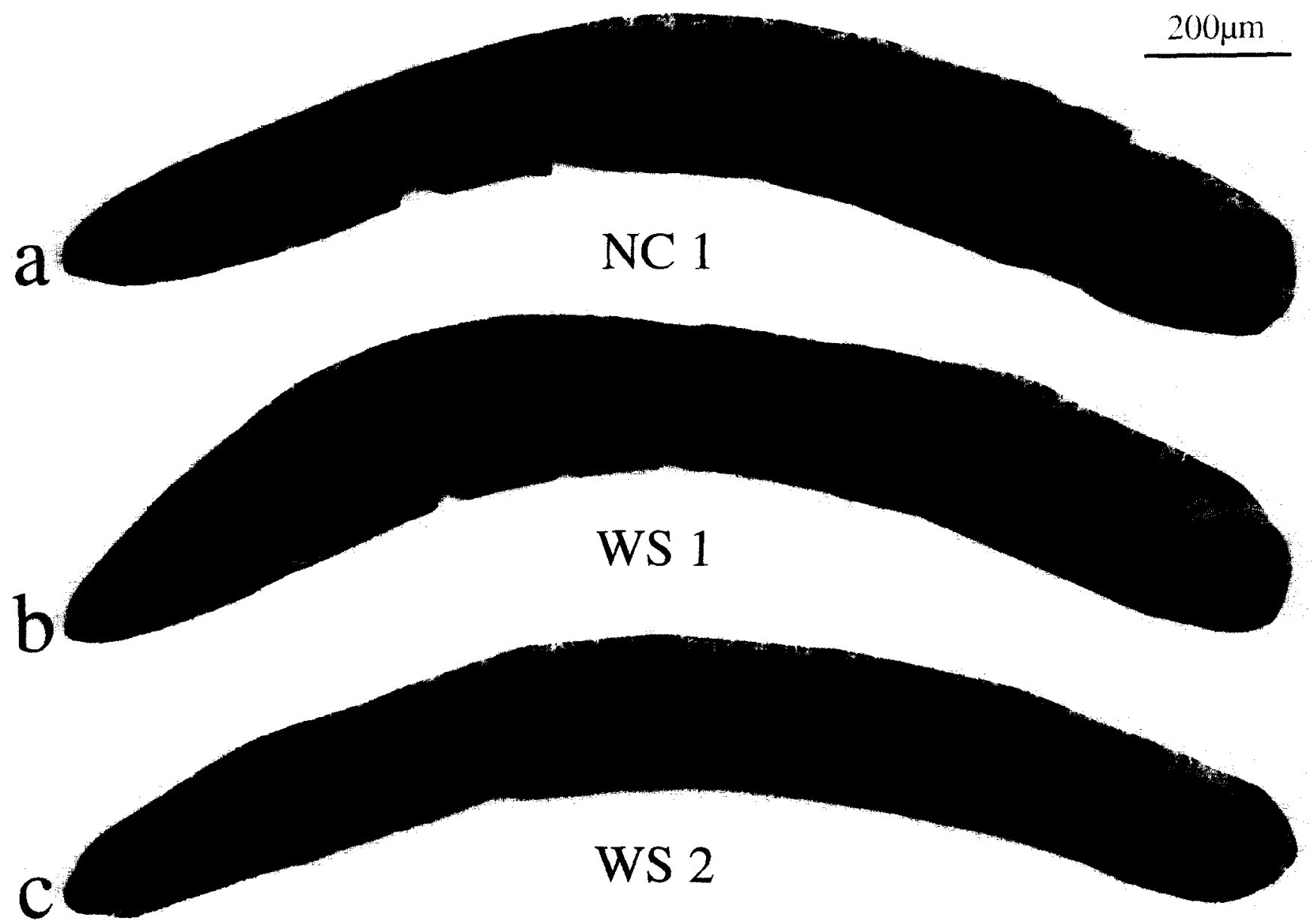

Fig. 2. $(a, b, c)$ Low power reconstructions of the basilar papillae of the three birds where behavioral audiograms have been determined. (a) $\mathrm{A}$ non-Waterslager canary NC 1, (b) and (c) Waterslager canaries WS 1 and WS 2.

as well as WS3 and WS4 represent the upper limit of the threshold distribution found in the respective groups. Thus NC2 had thresholds that were elevated compared to the average of other non-Waterslager CAP audiograms (unpublished data). However, these thresholds were well below those of the average Waterslager CAP audiogram (thin dotted line, unpublished data). For frequencies above $2 \mathrm{kHz}$ thresholds of $\mathrm{NC} 2$ were well below those of the most sensitive Waterslager in our sample. The Waterslager canary cochleae used for the anatomical study had the highest CAP thresholds in the low- and mid-frequency range among a group of 6 Waterslagers where CAP audiograms were measured. Threshold differences tended to be

Table 1

\begin{tabular}{|c|c|c|c|c|c|c|}
\hline & \multicolumn{3}{|c|}{ Waterslager canary } & \multicolumn{3}{|c|}{ Non-Waterslager canary } \\
\hline & Bird code & $\begin{array}{l}\text { Papillar length } \\
(\mu \mathrm{m})\end{array}$ & Hair cell number & Bird code & $\begin{array}{l}\text { Papillar length } \\
(\mu \mathrm{m})\end{array}$ & Hair cell number \\
\hline 'Behavior'-birds & $\begin{array}{l}\text { WS1 r } \\
\text { WS1 I } \\
\text { WS2 r } \\
\text { WS2 } 1\end{array}$ & $\begin{array}{l}1735 \\
1642 \\
1706 \\
1730\end{array}$ & $\begin{array}{l}3000 \\
1730\end{array}$ & $\begin{array}{l}\mathrm{NCl} \mathrm{r} \\
\mathrm{NCl} 1\end{array}$ & $\begin{array}{l}1676 \\
1686\end{array}$ & 3055 \\
\hline 'CAP' birds & $\begin{array}{l}\text { WS3 } 1 \\
\text { WS3 r } \\
\text { WS4 I }\end{array}$ & $\begin{array}{l}1706 \\
1740 \\
1750\end{array}$ & & $\begin{array}{l}\mathrm{NC} 21 \\
\mathrm{NC} 2 \mathrm{r}\end{array}$ & $\begin{array}{l}1568 \\
1671\end{array}$ & 3160 \\
\hline Average: & & $1716(N=7)$ & $2365(N=2)$ & & $1650(N=4)$ & $3108(N=2)$ \\
\hline
\end{tabular}


larger between Waterslager and control canaries at frequencies above $2 \mathrm{kHz}$ as compared to lower frequencies.

\section{Basilar papilla morphology}

Fig. 2 shows overviews of the right basilar papillae of the 3 birds studied in the behavioral experiments. The basilar papillae of the control birds displayed the very regular pattern of hair-cell and stereovillar-bundle arrangement typical for the avian basilar papilla (eg. NC1; Fig. 2a). It is obvious that the two papillae from the Waterslagers (Fig. 2b,c) showed different degrees of irregularities, with one papilla (WS2; Fig. 2c) being obviously more affected than the other (WS1; Fig. 2b). The length of the 3 papillae was similar, but it is already obvious from the overview that both the width and the total number of hair cells of the papilla shown in Fig. $2 \mathrm{c}$ was clearly smaller than that of the control papilla (Fig. 2a).

Papillar length was determined in both cochleae of all but one bird and is individually listed in Table 1 . The average papillar length was $1.72 \mathrm{~mm}$ in 7 cochleae of 4 Waterslagers and $1.65 \mathrm{~mm}$ in the 4 cochleae of our 2 control canaries. The length of the basilar papillae was obviously very similar between the Waterslager and control canaries with a trend for Waterslager basilar papillae to be slightly longer than those of the controls (Mann Whitney test; $\mathrm{n} 1=4 ; \mathrm{n} 2=7 ; \mathrm{U}=25$; $P=0.05$ ).

Due to dissection artefacts, the total number of hair cells could only be determined for 4 cochleae, one of each control animal and one of each Waterslager tested in the behavioral experiment. The hair-cell numbers are also listed in Table 1. The controls had slightly more than 3000 hair cells in each papilla. One Waterslager also had 3000 hair cells (WS1, Fig. 2b) while the other had almost half of the normal number (1730; WS2; Fig. 2c).

In order to obtain data from those papillae where the total hair-cell number could not be determined, we counted the number of hair cells in a $100 \mu \mathrm{m}$-wide strip across the papilla at a basal, middle and apical location. The average hair cell numbers and the standard deviations obtained from 4 non-Waterslager and 7 Waterslager cochleae in the $100 \mu \mathrm{m}$-wide strips were at $20 \%$ from the base $129 \pm 4$ versus $85 \pm 19$, at $50 \%$ from the base $192 \pm 18$ versus $142 \pm 37$ and at $80 \%$ from the base $255 \pm 16$ versus $178 \pm 52$. Thus, hair-cell numbers in Waterslagers were on average reduced by 34,26 and $30 \%$ at the base, middle and apex of the cochlea. In addition, the standard deviation among the Waterslagers was much higher than among the nonWaterslagers.

To characterize the hair-cell loss along the papilla in more detail, we counted the number of hair cells across the papilla at approximately 10 positions along its

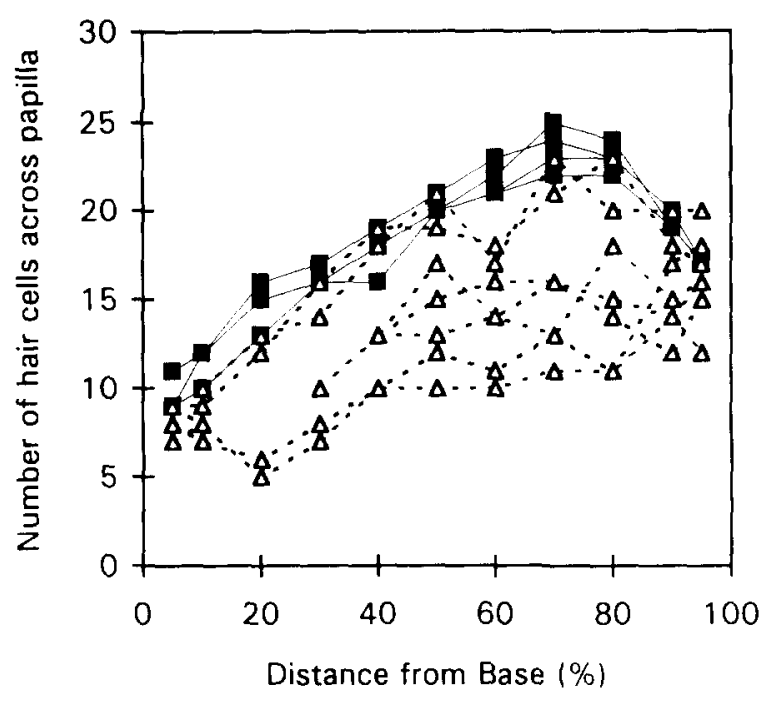

Fig. 3. The number of hair cells in different breeds of canary across the papilla as a function of the distance from the basal end. Data from non-Waterslager canaries are coded by filled symbols and continuous lines, data from Waterslager canaries are shown by open symbols and dotted lines.

length (Fig. 3). In Fig. 3 filled squares connected by continuous lines indicate data from individual control cochleae while the open triangles connected by dotted lines indicate data of cochleae from Waterslager canaries. The figure demonstrates that the values from the 4 control cochleae were fairly similar to each other, while variability was much larger among the data from the Waterslagers. It is worth mentioning that the 2 curves from Waterslager cochleae that are scattered among the values for the controls were both from the bird whose right cochlea is illustrated in Fig. $2 b$ and that looked fairly normal. From Fig. 3, we conclude that the Waterslager canaries had, on average, $30 \%$ fewer hair cells than normal control canaries, although there was obviously a large degree of variability ranging from normal to severely reduced numbers.

The width of the papilla was measured at the same positions where hair-cell counts had been performed. The data are shown for the controls (filled squares, continuous lines) and the Waterslagers (open triangles, dotted lines) in Fig. 4. The papillar width was rather similar among controls and reached a maximum of approximately $140 \mu \mathrm{m}$ between 60 and $80 \%$ of the distance from the base. The two cochleae from one of the 4 Waterslagers (WS1, illustrated in Figs. 2b and 3 as having normal hair-cell numbers) apparently had a normal papilla width. The width of the papillae of the other Waterslager canaries was clearly reduced as compared to the control birds. However, as with the haircell number, there was a large variability among the Waterslagers in the width of the papilla, ranging from normal to severely abnormal. 


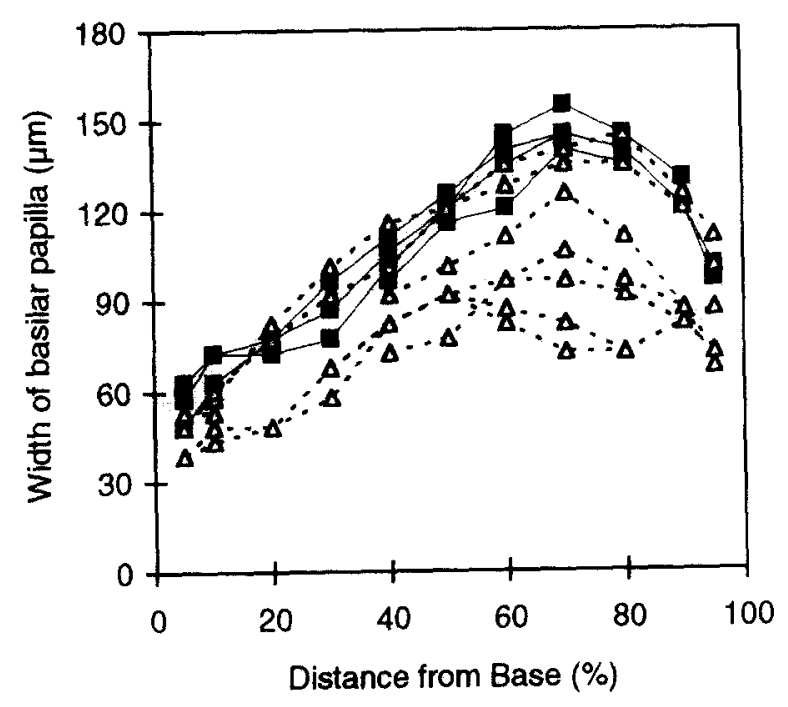

Fig. 4. The width of the basilar papilla as a function of the distance from the basal end. Data from non-Waterslager canaries are coded by filled symbols and continuous lines, data from Waterslager canaries are shown by open symbols and dotted lines. The papillar length is normalized.

Reconstructions with high-resolution micrographs of a strip across the papilla at $50 \%$ from the basal end are shown in Fig. 5. The specimens are the same as those shown in Fig. 2. The control cochlea (NC1; Fig. 5a) demonstrated a very regular pattern of hair cells, with orderly-arranged, elongated stereovillar bundles. The papilla from the Waterslager canary WSI (Fig. 5b) had a normal number of hair cells and a normal width of the papilla, however, the hair-cell mosaic and the stereovillar bundles were obviously disturbed. Bundle shapes varied from almost normal, elongated bundles, via almost round bundles to irregular bundle shapes and even to occasional bundles that had separated into several sub-bundles on the hair-cell surface. Some bundles consisted of very few stereovilli. Some hair cells had isolated villi of sometimes rather large dimensions located on their surface. While the orientation of the bundle on the hair-cell surface was very orderly in the control canary (Fig. 5a) this orientation, as far as it could be deducted from the pathologic bundles, also appeared rather distorted in WS1. All these pathologies, but in an even more exaggerated form, were also found in the cochleae of the 3 other Waterslagers (e.g. Figs. 3 and 4). One of the most severe cases is illustrated in Fig. 5c (WS2). In this bird, the width of the papilla was also quite severely affected. In the more severely affected birds, an additional type of 'abnormal' hair cell was rather prominent. These hair cells had a small surface area that was covered to a varying degree by microvilli. The stereovillar bundle was often quite small in these hair cells. In addition, there were occa-

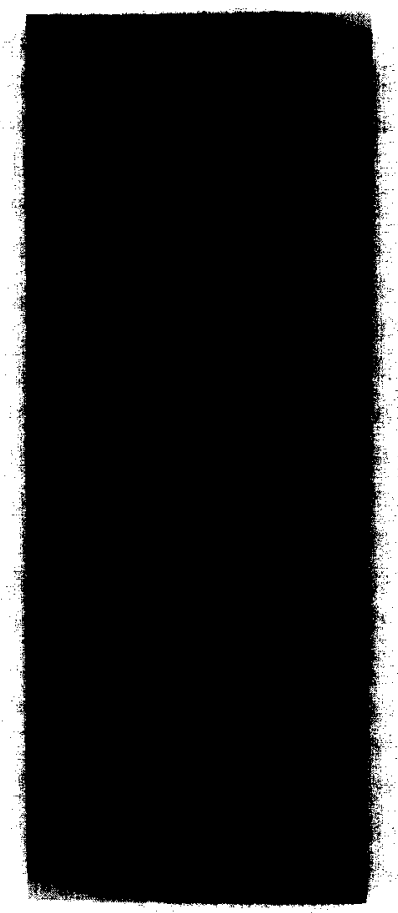

a) $\mathrm{NC1}$

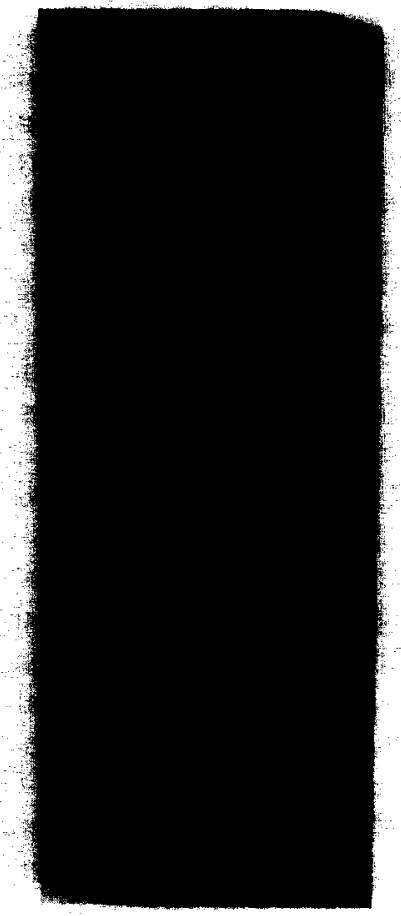

b) WS1

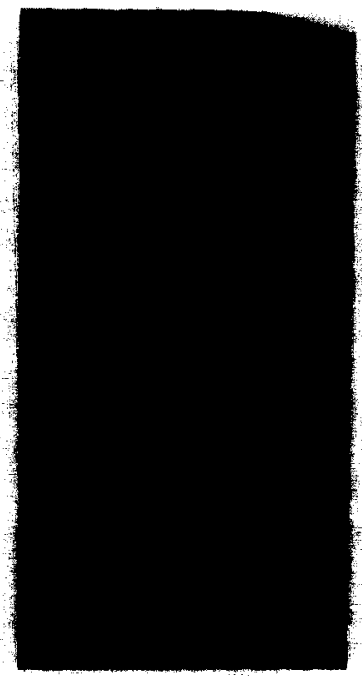

c) WS2

\section{$20 \mu \mathrm{m}$}

Fig. 5. (a,b,c) High power reconstructions of a strip across the papilla in the middle, between the base and the apex of the basilar papilla. (a) a non-Waterslager canary NC1, (b) and (c) Waterslager canaries WS 1 and WS 2. 

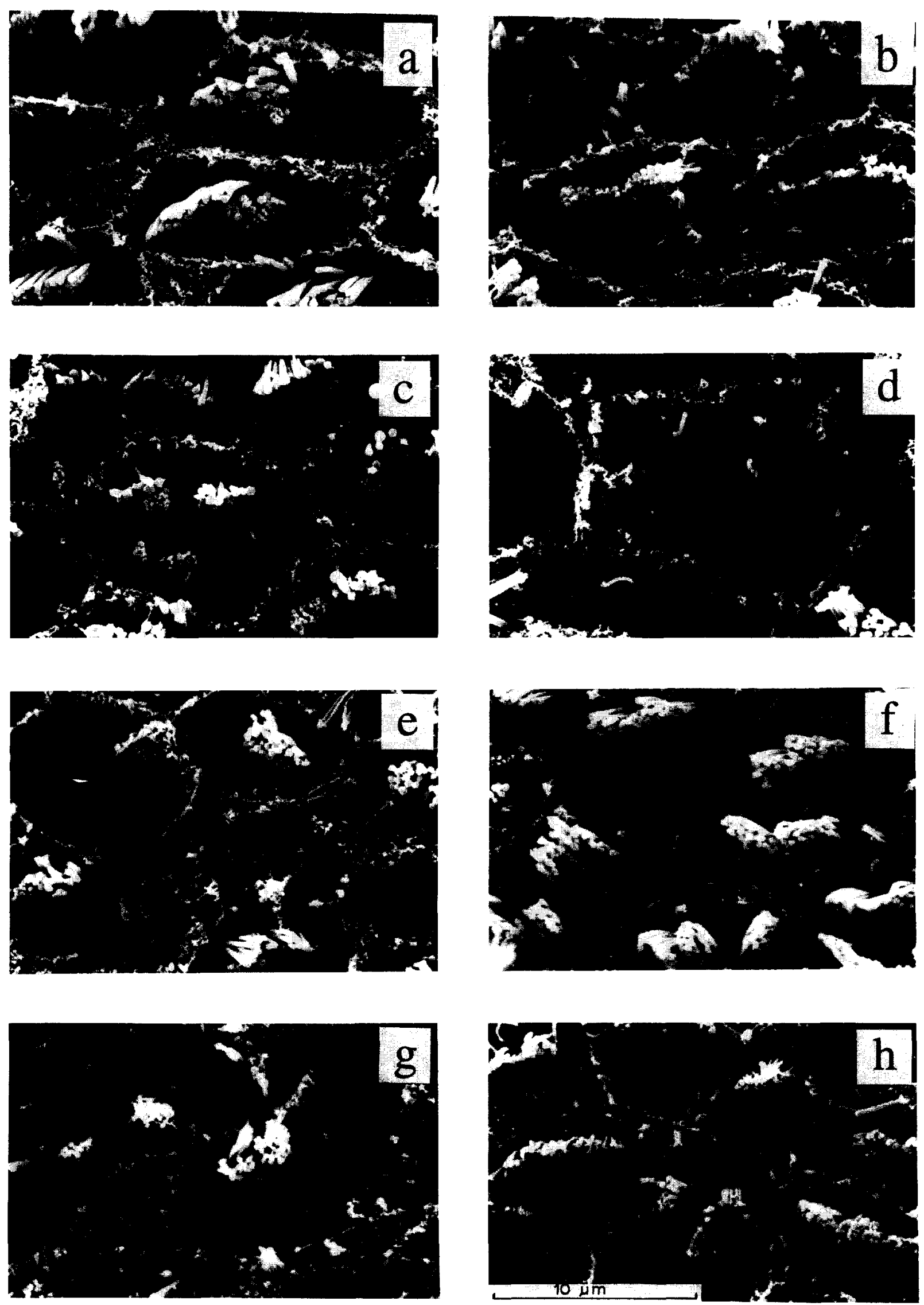

Fig. 6. (a-h) High power pictures of selected examples of pathological hair cells that were typically found in the Waterslager canaries. 
sional microvilli-rich patches that had no stereovillar bundle recognizeable under the SEM.

Selected examples of the different hair-cell pathologies are shown in Fig. 6. An almost normal bundle with just a few missing stereovilli is illustrated in Fig. 6a, while the adjacent hair cell above appears more severely disrupted. Fig. 6b illustrates bundles with extremely abnormal shapes. Stereovillar bundles were fragmented into subbundles (Fig. 6c) or almost completely missing (Fig. 6d). There were also hair cells with gigantic (Fig. 6e) or very thin stereovilli (Fig. 6f). The bottom row (Fig $6 \mathrm{~g}, \mathrm{~h}$ ) illustrates cases of hair cells with a small surface area that was covered by microvilli and only small stereovillar bundles.

The number of stereovilli was counted from highmagnification prints looking perpendicular onto the papillar surface. Due to the abnormal bundle shapes and stereovilli of very variable diameter on a single hair cell (eg. Fig. 6), counting stereovilli was rather difficult in the Waterslager canaries. Hair cells where the surface was covered by microvilli were excluded from the analysis, otherwise an attempt was made to count the villi numbers in representative samples of hair cells across the whole papilla. Fig. 7 compares the villar numbers from the non-Waterslagers (filled symbols) and from the Waterslager canaries (open symbols). The figure illustrates for all three positions analyzed (a: $20 \%$; b: $50 \%$; c: $80 \%$ distance from the base) that the villar numbers were reduced in all Waterslager canaries as compared to the controls. In addition the villar number for a given position on the papilla was much more variable in Waterslagers than in the controls. It is worth mentioning that the villar numbers in the Waterslager with obviously normal gross papillar dimensions (WS1, coded by open triangles in Fig. 7) were on average well below those of the controls, but they were on average higher than those of the other Waterslager tested behaviorally (WS2, coded by open circles in Fig. 7).

The apical surface area was determined for the same hair cells where the villi numbers had been counted. Fig. 8 compares the apical hair-cell areas measured in non-Waterslagers (filled symbols) and Waterslager canaries (open symbols) at three different positions along the papilla (a: $20 \%$, b: $50 \%$, c: $80 \%$ from the basal end). It is obvious that the apical hair-cell surface was on average larger in the Waterslagers and that it showed a much greater degree of variability as compared to the data from the nonWaterlsagers. At $50 \%$ and $80 \%$ from the base, the difference between the two canary strains appeared smaller in the neural third of the papilla as compared to the abneural part. Again the Waterslager that had normal gross papillar dimensions (WS2, open triangles in Fig. 8) had apical hair cell surfaces that were larger than those of the non-Waterslagers but appeared less
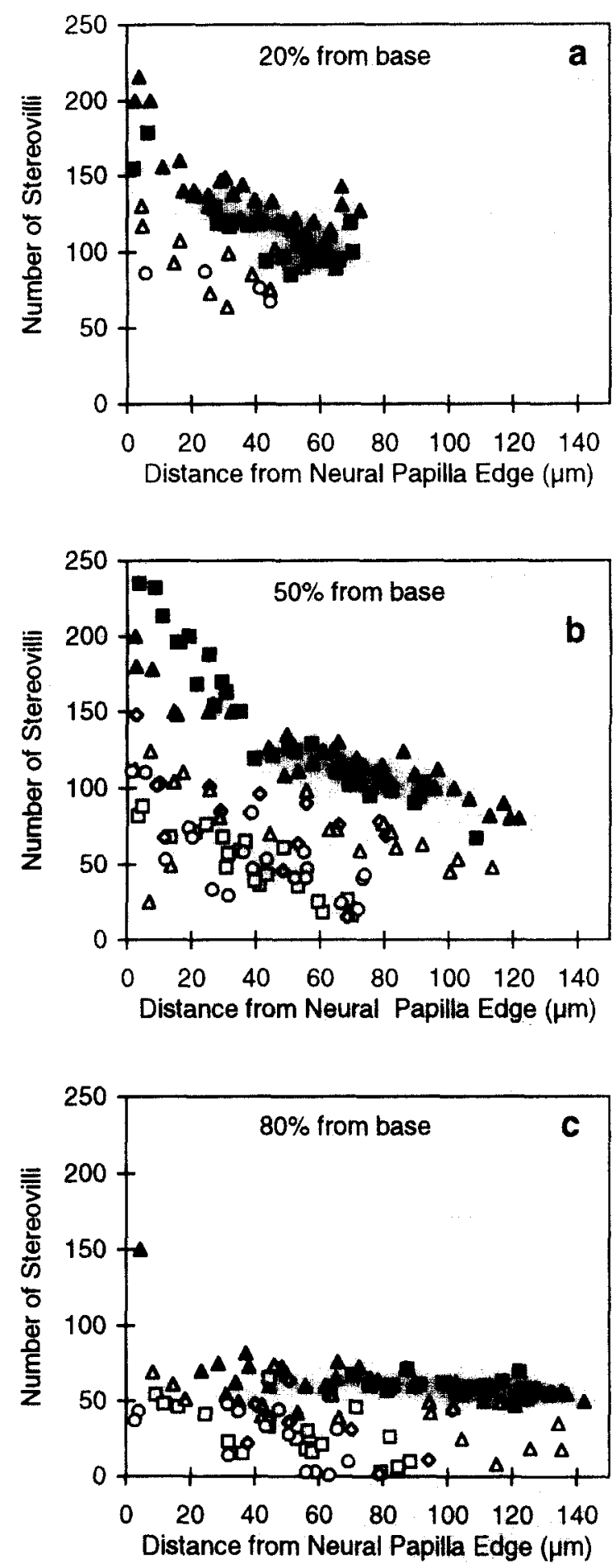

Fig. 7. (a,b,c) The number of stereovilli of individual hair-cell bundles as a function of the distance from the neural-edge of the papilla. Filled symbols code data from two non-Waterslager canary cochleae, while open symbols code data from 4 Waterslager cochleae. (a) $20 \%$ from the basal end, (b) $50 \%$ from the basal end and (c) $80 \%$ from the basal end of the papilla.

affected than those of the other Waterslager tested behaviorally (WS2, coded by open circles in Fig. 8)

Because many other hair-cell parameters could not 
be measured usefully in the Waterslager canaries, we had the degree of hair-cell abnormality graded by volunteers. Fig. 9a and b illustrate the grades assigned to hair cells by one volunteer as a function of the
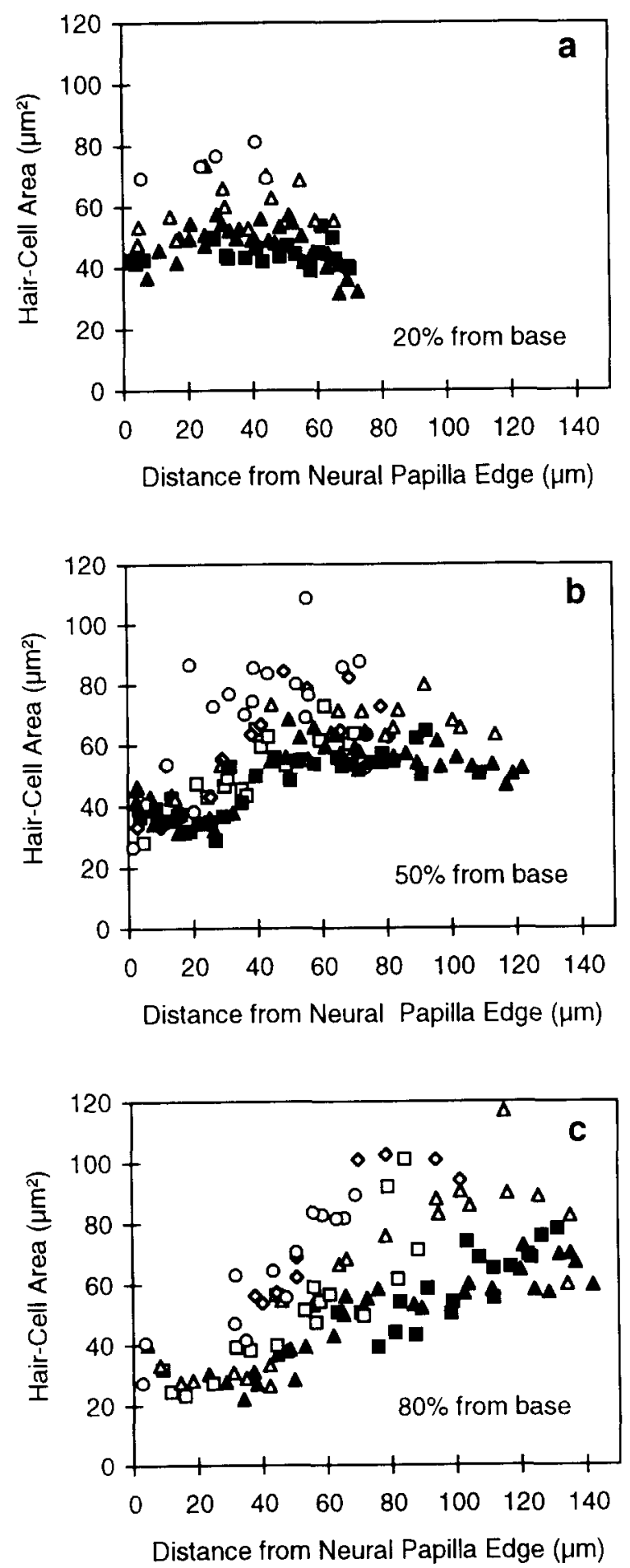

Fig. 8. (a,b,c) The apical hair-cell surface area as a function of the distance from the neural edge of the papilla. Filled symbols code data from two non-Waterslager canary cochleae, while open symbols code data from 4 Waterslager cochleac. (a) $20 \%$ from the basal end. (b) $50 \%$ from the basal end and (c) $80 \%$ from the basal end of the papilla. distance from the neural edge of the papilla at 80 and $50 \%$ from the basal end in one specimen. The data are from the papilla illustrated in Fig. $2 c$ and Fig. 5c. It is obvious that neighboring hair cells are often quite differently affected. At a given position on a papilla (e.g. neural side of the specimen illustrated in Fig. 2c and Fig. $5 \mathrm{c}$ ), the grades of neighboring hair cells can vary from almost normal to severely abnormal. The smoothed weighted average (line; Cleveland, 1979). however, indicates that despite local variability, gradients do exist across the papilla.

The grades assigned to individual hair cells by the different volunteers were in general very similar. This is illustrated in Fig. 9c and $\mathrm{d}$ that show as thin lines the smoothed averages from the 5 different volunteers together with the averaged function (heavy line) calculated from the pooled grades of all volunteers. Thus, although each volunteer assigned the classification on a subjective basis, all came to similar conclusions.

A summary of the hair-cell classifications from the pooled data is shown in Fig. 10. The heavy continuous and dotted lines code data from the two Waterslagers tested behaviorally, while the light lines stand for the two Waterslager cochleac tested by CAP audiograms. Over all, there was a large variability of the hair-cell grades among the 4 papillae investigated. However, all of the cochlear regions appeared at least slightly affected, the best average grade found in Waterslagers being around 2 . At the base (Fig. 10a) a median grade of hair-cell pathology was found across the papilla. In the middle of the papilla (Fig. 10b) 3 of the 4 papillac showed an increase of the hair-cell pathologies towards the abneural side. Near the apex (Fig. 10c), all 4 papillae showed an increase of hair-cell pathology from the neural towards the abnewal side. Generally, the bird with normal over-all basilar-papilla dimensions (WS1; illustrated in Fig $2 \mathrm{~b}$ and $5 \mathrm{~b}$ ) showed the least hair-cell pathology (thick continuous line in Fig. 10). Figs. 5, 9 and 10 demonstrate that in the Waterslagers canaries, almost no completely-normal hair cells could be found.

\section{Discussion}

Though it has been known for several years that there are strain differences in auditory sensitivity in canaries, it remained unclear whether these elevated thresholds were due to middle ear, cochlear or central nervous anomalities (Okanoya and Dooling, 1985; 1987). There were indications, however, that this phenomenon has a genetic basis (Okanoya et al., 1990). Recently, compound action potential measurements indicated that the auditory deficit of Waterslager canaries is already present at the level of the auditory nerve (Gleich and Dooling, 1992). In the present study, 
we demonstrate that differences in auditory sensitivity between Waterslager canaries and canaries of other strains are associated with pathological changes in hair cells of the Waterslager basilar papilla.

One important finding in this study is that the basilar-papilla condition could be directly correlated with the audiogram of the respective individual. Unfortunately, due to methodological differences, CAP- audigrams differ systematically from behavioral audiograms in birds (Gummer et al., 1987; Gleich, Klump and Dooling, in prep.) and can not be directly compared. There exists a large database for avian behavioral audiograms (review in Dooling, 1992); however, avian CAP audiograms are scarce in the literature. Thus, to correlate the audiogram and the basilar-papilla morphology, we rely mainly on the birds tested behaviorally and use data from the birds tested by CAP measurements as a supplement. Nevertheless, we es- tablished by the CAP measurements that the birds bought as Waterslagers and used for the anatomical study did indeed have thresholds elevated by $15 \mathrm{~dB}$ below $1 \mathrm{kHz}$ and by more than $40 \mathrm{~dB}$ above $3 \mathrm{kHz}$, as compared to normal (control) canaries.

The anatomical investigation of the basilar papillae from the 4 Waterslagers revealed that they all showed systematic anatomical abnormalities as compared to the control canaries. Detailed examination of their hair cells revealed abnormalities not usually seen in the controls or in other bird species (e.g. starling, pigeon; Gleich and Manley, 1988; chicken, Tilney et al., 1987). In the barn owl, however, Fischer et al. (1988) reported the presence of 'a few scattered hair cells whose appearance differed from the normal'; these hair cells share characteristics of the abnormal hair cells we found in the Waterslager canary. These abnormalities include incomplete bundles with irregular stereovilli,

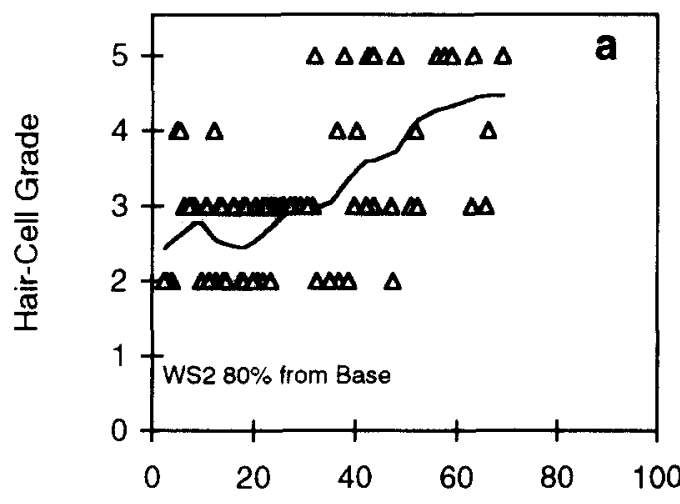

Distance from Neural Papilla Edge $(\mu \mathrm{m})$

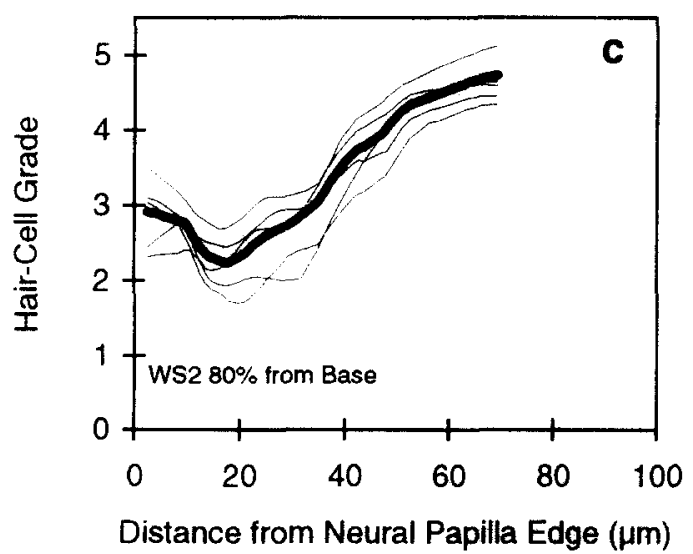

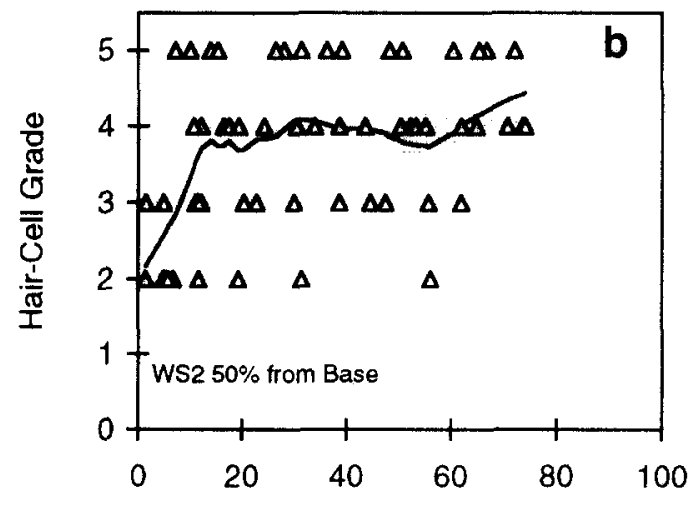

Distance from Neural Papilla Edge $(\mu \mathrm{m})$

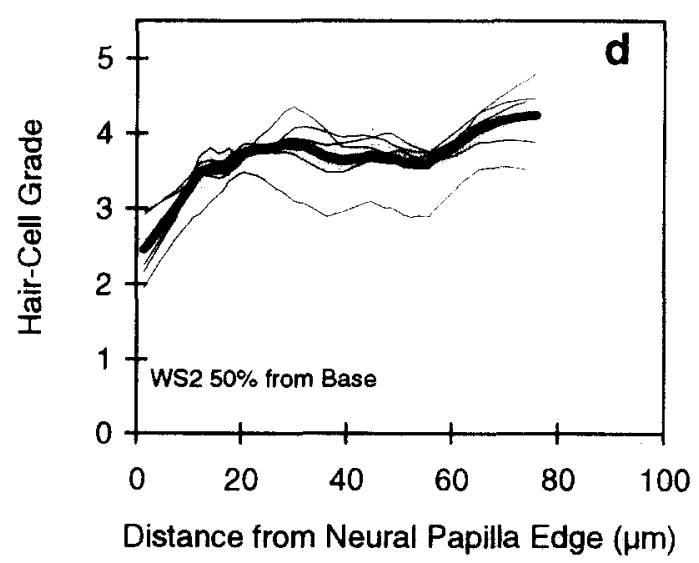

Fig. 9. (a-d) Classification of hair-cell condition on a scale between 1 (normal) and 5 (extremely abnormal) as a function of the distance from the neural edge. ( $a$ and b) Data for one observer from two positions of one Waterslager papilla. Each open triangle shows the 'grade' of a single hair cell. The continuous line is the smoothed weighted average through the data. (c, d) The smoothed weighted avaerages of the grading by 5 different observers shown as thin lines for the same data as illustrated in (a) and (b). The heavy lines are the averages of all grades assigned by the 5 different observers. 

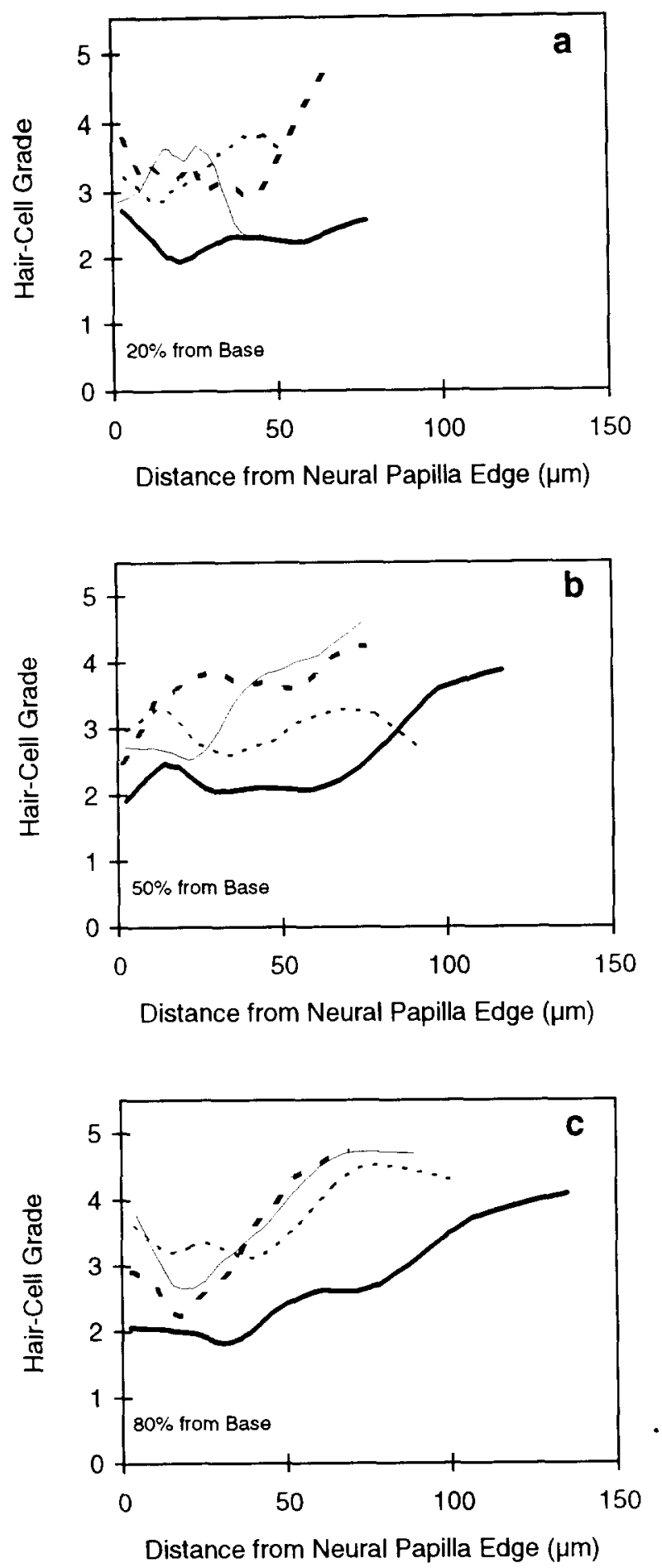

Fig. 10. (a,b,c) The hair-cell condition (grade) as a function of the distance from the neural papilla edge. The heavy lines show data from the birds tested behaviorally (continuous line WS 1; dotted line WS 2). The thin lines show data from the birds for which CAP. audiograms are available. (a) $20 \%$ from the basal end, (b) $50 \%$ from the basal end and (c) $80 \%$ from the basal end of the papilla.

hair cells with fragmented bundles due to missing stereovilli and hair cells with microvilli covering their apical surface. However, in contrast to the situation in the Waterslagers, these abnormal hair cells formed a tiny minority among normal hair cells in the barn owl.
The fact that all Waterslagers examined had similar hair-cell pathologies, independently of whether they were purchased in Germany or the USA indicates that this abnormality is a widespread characteristic of the Waterslager canary strain with an origin probably dating back to the time before the first birds were transferred from Europe to the USA. Although the cochleae of one Waterslager obviously had normal proportions (e.g. papilla width; number of hair cells), even the gross proportions of the others were obviously affected to a varying degree (Figs. 2, 3 and 4). Thus there was a considerable variability of cochlear pathology among the Waterslagers. In severe cases of pathology hair-cell numbers and the width of the papilla were reduced, while in less severe cases only individual hair cells and especially their stereovillar bundles were affected. We do not know the exact reasons for the variability of the morphological defects that we observed, but we strongly suspect that they represent differences among different breeding lines. Okanoya et al. (1990) showed in hybrids of a Waterslager and a Roller canary that thresholds varied from normal via intermediate to severely affected. Thus differences in genetic background are an attractive explanation for the variability we found.

In the case of the two Waterslagers tested behaviorally, we were fortunate to have two birds that showed different degrees of cochlear pathology. Thus we can compare the effect of different degrees of pathology on the auditory performance, albeit only in two individuals. In a low-power overview, the Waterslager papilla illustrated in Fig. 2b appeared rather normal and showed only minor irregularities compared to the control (Fig. 2a). However, despite the normal number of hair cells and normal gross structures of the papilla, thresholds of WS 1 were severely elevated compared to the control NC1 (Fig. 1a, open triangles, heavy dotted lines versus open squares, heavy continuous line), especially at frequencies above $1 \mathrm{kHz}$. Thus although gross structures appeared fairly normal in this cochlea, the pathology of individual hair cells (Fig. 5b; Fig. 7, Fig. 8, Fig. 10 continuous thick line) was sufficient to cause elevation of thresholds of $20-40 \mathrm{~dB}$ for frequencies above $1 \mathrm{kHz}$. The papilla illustrated in Fig. 2c appears much more affected, with a $40 \%$ reduction of the hair-cell number (Table 1) and a similar reduction of the papillar width (Figs. $2 \mathrm{c}$ and $5 \mathrm{c}$ ) as compared to the controls, and compared to the other Waterslager (Fig. 2b). However, this massive additional pathology of the gross structure in conjunction with the hair-cell damage in WS2 caused only an additional 10-20 dB threshold shift above $1 \mathrm{kHz}$ as compared to the less affected Waterslager WS1 (Fig. 2b,c; Fig. 1: open triangles versus open circles). In this context, it would be very interesting to examine the basilar papilla of hybrids with intermediate ranges of auditory deficits.

As in previous behavioral studies (Okanoya and 
Dooling, 1985; 1987; Okanoya et al., 1990) we found that the threshold difference between Waterslagers and controls is much larger for frequencies above 1 $\mathrm{kHz}$ than for lower frequencies. We do not know the frequency distribution along the canary basilar papilla, but from the known tonotopy in other birds (chicken, Manley et al., 1987; starling, Gleich, 1989; barn owl, Köppl et al., 1993) we know that the high frequencies are represented at the base and low frequencies at more apical locations of the papilla. Thus from the audiogram data, one could attempt to predict a gradient of pathology with the apex being less affected than more basal parts of the papilla. However, inspection of the papillae in the overview (Fig. 2) and at 20,50 and $80 \%$ from the base (Fig. 5) as well as evaluation of hair-cell pathology (Fig. 10) did not reveal an obvious apical-to-basal gradient in cochlear pathology. Indeed, abneural hair cells appear on average to be more affected near the apex than at the base (Fig. 10). We have no explanation for this paradox, especially since the anatomical difference between the two Waterslager canaries from the behavioral experiment obviously extended along the whole length of the basilar papilla, but their thresholds at $1 \mathrm{kHz}$ were virtually identical. This reflects our inadequate understanding of the function of the avian basilar papilla.

A prerequisite for comparing anatomy: and physiology in terms of basilar papilla location and threshold at specific test frequencies is the knowledge of the frequency distribution on the basilar papilla. Although we can assume for normal canaries that high frequencies are represented at the base while the low frequencies are represented at the apex of the cochlea, similar to other birds and in mammals, we do not now any details of the frequency map of the canary cochlea. We also do not know the frequency representation in the cochlea of Waterslager canaries which may very well be different. The pathological changes that we found in the basilar papilla of the Waterslager canary could affect the frequency mapping by changing the mechanical properties of the basilar papilla: - tectorial membrane complex as well as the micromechanical properties of individual stereovillar bundles. Despite the many different pathological changes we found (eg. very irregular bundle shapes, multiple bundles, variable villi diameters etc.) and whose effects on the mechanical properties of the bundles we do not yet understand, we found that the number of stereovilli at a given basilar papilla location is reduced in Waterslagers as compared to control birds (Fig. 7). The reduction in the number of stereovilli could lead to a reduced stiffness and thus a lower resonance frequency of the local resonant system that is mechanical interactions between stereovillar bundles, the hair cells and the basilar and tectorial membrane (Manley and Gleich, 1992).
In birds, the micro mechanical mechanisms of tuning appear to become more important above $1 \mathrm{kHz}$, while at lower frequencies other mechanisms (eg. electrical tuning) may dominate (Manley, 1986; Manley and Gleich, 1992). Thus the change in the mechanical properties of the stereovillar bundles as a result of the reduced number of stereovilli might contribute to the observation that higher frequencies are more affected than lower frequencies in Waterslager canaries. Alternatively, or in addition, effective use of phase locking information might contribute to the comparatively good thresholds of Waterslager canaries at low frequencies because phase locking of single auditory afferents in the starling is high for frequencies below $1 \mathrm{kHz}$ and decreases rapidly above $1 \mathrm{kHz}$ (Gleich and Narins, 1988). Furthermore, the hair-cell pathology could affect the innervation pattern of basal areas of the Waterslager basilar papilla more severely than apical areas.

There have been a number of studies describing cochlear pathology in birds as a result of acoustic overstimulation (Cotanche, 1987; Cotanche et al., 1987; Cotanche and Corwin, 1991; Cousillas and Rebillard, 1988; Corwin and Cotanche, 1988; Girod et al., 1989; Saunders et al., 1992) and ototoxicity of antibiotic drugs (Hashino et al., 1992; Hashino et al., 1991; Girod et al., 1991; Pickles and Rouse, 1991). We can thus compare the pathologies found in the cochlea of the Waterslagers with those observed in other birds after insult to the cochlea. In general, on the level of the hair cells, we find the same types of pathologies described for acoustic overstimulation or ototoxicity in the chick or budgerigar in our Waterslager cochleae. An important difference is that the abnormalities in the Waterslager appeared to affect the whole basilar papilla, while ototoxic antibiotics and acoustic trauma cause variable damage that affects only part of the papilla. We find many hair cells with rather large apical suface areas (Fig. 5c vs 5a; Fig. 6, middle right; Fig. 8) an abnormality described after acoustic overstimulation (Cousillas and Rebillard, 1988) and aminogylcoside intoxication (Pickes and Rouse, 1991; Hashino et al., 1991). A varying degree of stereovillar bundle disruption similar to our findings in the Waterslager (Figs. 5 and 6) was described after insult to the chick or budgerigar cochlea (Cotanche et al., 1987; Cotanche, 1987; Cousillas and Rebillard, 1988; Hashino et al., 1992; Hashino et al., 1991; Pickles and Rouse, 1991). After acoustic overstimulation, Cotanche et al. (1987) found surviving hair cells in the damaged areas that had reduced numbers of stereovilli. This corresponds to a reduced number of stereovilli we found in Waterslager canaries (Fig. 7).

Our quantitative analysis of morphological parameters across the papilla can also be used to determine if 
different hair-cell populations (eg. tall and short hair cells) are affected differently. In the canary basilar papilla many morphological parameters vary between the neural and the abneural edges, however, an unequivocal distinction between tall and short hair cells is not possible on the basis of a SEM analysis of the papillar surface (Gleich et al., 1994). Nevertheless we can compare the degree of abnormalities found in neural and abneural hair cells. The data presented in Figs. 7 and 8 and 10 clearly demonstrate that pathologies vary differently across the papilla, depending on the parameter investigated. Neural and abneural haircell populations in Waterslagers both show considerable abnormalities, however, the pattern of damage does not allow a clear distinction of tall and short hair cells.

Remarkable is the presence of hair cells with small surface areas that were more prominent in the more affected cochleae and which had many microvilli and variably sized stereovillar bundles in our Waterslager material (Fig. 5c and 6, bottom). These hair cells resemble in great detail those that were observed after insult to the cochlea and were described as regenerating hair cells (Pickles and Rouse, 1991; Hashino et al., 1991; Girod et al., 1991; Cotanche 1987; Cotanche and Corwin, 1991). This observation suggests that in severely-affected Waterslager canaries, there may be a continuous turn-over of sensory cells with a steady production of new hair cells even in the adult bird.

There has recently been considerable interest in the genetics of hearing impairment in both humans and animals (Steel, 1991). The most popular vertebrate studied to date has been the mouse where over 70) strains of inner-ear mutations have been found (Steel et al., 1983; Steel, 1991). Many of them were first identified from external mutations (i.e. pigmentation or motor deficit) with auditory deficits being discovered later. In many strains, the exact loci of the abnormality have been identified (Steel, 1991). The hearing abnormality we describe in Waterslager canaries almost certainly has a hereditary basis. While it remains to be seen whether the canary will turn out to be a useful preparation for studying the genetic mechanisms of hearing impairment, the canary does provide special opportunities. In contrast to the mouse, the canary offers the opportunity to understand the relation between hearing impairment and vocal behavior since the vocalizations of this species are learned. In addition, there are important questions which arise from the present results as to whether the Waterslager cochlea develops normally and whether adult Waterslager canaries show a more-or-less continuous hair-cell regeneration process. Moreover, if the regeneration process is operating as it does in other avian species, why does regeneration fail to correct the hearing impairment observed in this species?

\section{Acknowledgements}

This work was supported by a Helmholtz grant from the BMFT to OG, a Humboldt Forschungspreis and NIH (DC00198 and MH00982) grants to RJD and by the Deutsche Forschungsgemeinschaft within the program of the SFB 204 ('Gehör'). A. Linzenboldt trained the 'behavioral birds' and measured their audiograms. We thank Prof. J. Strutz for support and comments and the observers K. Bielenberg, B. Gleich, Dr. P. Kwok, E. Richter and Dr. J. Wies for evaluating the degree of hair-cell pathology. C. Cavannah helped with photography.

\section{References}

Brown. S.D. and Bottjer. S.W. (1993) Testosteronc-induced changes in adult canary brain are reversible. J. Neurobiol. 24.

Cleveland, W.S. (1979) Robust locally weighted regression and smoothing scatterplots. J. Am. Stat. Ass. 74, 829-836.

Corwin. J.T. and Cotanche. D.A. (1988) Regeneration of sensory hair cells after acoustic trauma. Science 241), 1772-1774.

Cotanche, D.A. (1987) Regeneration of hair cell stereociliary bundles in the chick cochlea following severe acoustic trauma. Hear Res. 30, 181-196.

Cotanche, D.A., Saunders. J.C. and Tilney, L.G. (1987) Hair cell damage produced by acoustic trauma in the chick cochlea. Hear. Res. 25, 267-286.

Cotanche. D.A. and Corwin, J.T. (1991) Stereociliary bundles reori ent during hair cell development and regeneration in the chick cochlea. Hear. Res. 52. 379-402.

Cousillas, H. and Rebillard, G. (1988) Morphological transformation of hair cells in the chick basilat papilla following an acoustic overstimulation. Hear. Res. 32. 117-122.

Dooling, R.J. (1982) Auditory perecption in birds. In: D.E. Kroodsma and E.H. Miller (Eds.), Acoustic communication in hirds, Vol. 1. Academic Press, New York. pp. 95-130.

Dooling, R.J. (1992) Hearing in hirds. In: R.R. Fay and A.N. Popper (Eds.). The evolutionary biology of hearing. Springer-Verlag. New York, pp. 545-5.59.

Fischer, F.P.. Köppl. C. and Manley. G.A. (1988) The basilar papilla of the barn owl Tyto alba: $A$ quantitative morphological SEM analysis. Hear. Res. 34, 87-102

Girod, D.A., Duckert, L.G. and Rubel, E.W (1989) Possible precur sors of regenerated hair cells in the avian cochlea following acoustic trauma. Hear. Res. 42. 175-194.

Girod. D.A., Tucci. D.L. and Rubel. F.W (1991) Anatomical correlates of functional recovery in the avian inner ear following aminoglycoside ototoxicity. Laryngoscope $101,1139-1149$.

Gleich, O., Manley, G.A., Mandl, A. and Dooling. R.J. (1994) The basilar papilla of the canary and the zebra finch: A quantitative scanning electron microscopical description. J. Morphol. 221, $1-24$.

Gleich. O. (1989) Auditory primary afferents in the starling: Correla tion of function and morphology. Hear. Res. 37, 255-268.

Gleich. O. and Dooling. R.J. (1992) The origin of the auditory deficit of 'Waterslager Canaries'. In: N. Elsner and D.W. Richter (Eds.), Rhythmogenesis in neurons and networks. Creorg Thieme Verlag, Stuttgart. New York, p. 207.

Gleich. O. and Manley. G.A. (1988) Quantitative morphological analysis of the sensory epithelium of the starling and pigeon basilar papilla. Hear. Res. 34, 69-86. 
Gleich, O. and Narins, P.M. (1988) The phase response of primary auditory afferents in a songbird (Sturnus culgaris L.). Hear. Res. $32,81-92$.

Gummer, A.W., Smolders, J.W.T. and Klinke, R. (1987) Basilar membrane motion in the pigeon measured with the Mössbauer technique. Hear. Res. 29, 63-92.

Guttinger, H.R. (1985) Consequences of domestication on the song structures in the canary. Behaviour $92,255-278$.

Hashino, E., Tanaka, Y., Salvi, R.J. and Sokabe, M. (1992) Hair cell regeneration in the adult budgerigar after kanamycin ototoxicity Hear. Res. 59, 46-58.

Hashino, E., Tanaka, Y. and Sokabe, M. (1991) Hair cell damage and recovery following chronic application of kanamycin in the chick cochlea. Hear. Res. 52, 356-368.

Köppl, C.. Gleich, O. and Manley, G.A. (1993) An auditory fovea in the barn owl cochlea. J. Comp. Physiol. A, 171, 695-704.

Manley, G.A. (1986) The evolution of the mechanisms of frequency selectivity in vertebrates. In: B.C.J. Moore and R.D. Patterson (Eds.), Auditory frequency selectivity. Plenum Press, New York. London, pp. 63-77.

Manley, G.A. and Gleich, O. (1992) Evolution and specialization of function in the avian auditory periphery. In: D.B. Webster, R.R. Fay and A.N. Popper (Eds.), The evolutionary biology of hearing. Springer Verlag, New York, pp. 561-580.

Manley, G.A., Brix, J. and Kaiser, A. (1987) Developmental stability of the tonotopic organization of the chick's basilar papilla. Science $237,655-656$.

Marler, P. and Waser, M.S. (1977) Role of auditory feedback in canary song development. J Comp. Phys. Psych. 91, 8-16.

Nottebohm, F. (1981) A brain for all seasons: Cyclical anatomical changes in song control nuclei of the canary brain. Science 214 , $1368-1370$.

Okanoya, K. and Dooling, R.J. (1985) Colony differences in auditory thresholds in the canary (Serinus canarius). J. Acoust. Soc. Am. $78,1170-1176$.

Okanoya, K. and Dooling, R.J. (1987) Strain differences in auditory thresholds in the canary (Serinus canarius). 1. Comp. Psychol $101,213-215$

Okanoya, K. and Dooling, R.J. (1990a) Detection of auditory sinusoids of fixed and uncertain frequency by budgerigars (Melopsittacus undulatus) and zebra finches (Poephila guttata). Hear. Res. $50,175-184$.

Okanoya, K. and Dooling, R.J. (1990b) Detection of gaps in noise by budgerigars (Melopsittacus undulatus) and zebra finches (Poephila guttata). Hear. Res. 50, 185-192.

Okanoya, K., Dooling, R.J. and Downing, J.D. (1990) Hearing and vocalizations in hybrid Waterslager-Roller canaries (Serinus ca. narius). Hear. Res. 46, 271-276.

Patuzzi, R.B. and Bull, C.L. (1991) Electrical responses from the chicken basilar papilla. Hear. Res. 53, 57-77.

Pickles, J.O. and Rouse, G.W. (1991) Effects of streptomycin on development of the apical structures of hair cells in the chick basilar papilla. Hear. Res. 55, 244-254.

Saunders, J.C., Adler, H.J. and Pugliano, F.A. (1992) The structural and functional aspects of hair cell regeneration in the chick as a result of exposure to intense sound. Exp. Neurol. 115, 13-17.

Steel, K.P. (1991) Similarities between mice and humans with hereditary deafness. In: R.J. Ruben, T.R. Van de Water and K.P. Steel (Eds.), The Genetics of hearing impairment. Annals of the New York Academy of Sciences, Vol. 630. The New York Academy of Sciences, New York, pp68-79.

Steel, K., Niaussat, M. and Bock, G. (1983) The genetics of hearing. In: J. Willott (Ed.), The auditory psychobiology of the mouse. Charles C Thomas, Springfield, IL, pp. 341-394.

Stresemann, E. (1923) Zur Geschichte einiger Kanarienvogel-Rassen. Ornith. Monatsber. 31, 103-106.

Tilney, M.S., Tilney, L.G. and DeRosier, D.J. (1987) The distribution of hair cell bundle lengths and orientations suggests an unexpected pattern of hair cell stimulation in the chick cochlea. Hear. Res. 25, 141--151.

Waser, M.S. and Marler, P. (1977) Song learning in canaries. J. Comp. Phys. Psych. 91, 1-7. 